\title{
Pengaruh Pemanfaatan Aplikasi Keluarga Sehat terhadap Kinerja Petugas Promosi Kesehatan Puskesmas
}

\author{
Ekowati $^{*)}$, Zahroh Shaluhiyah ${ }^{*}$, Farid Agushybana ${ }^{*)}$ \\ *) Fakultas Kesehatan Masyarakat Universitas Diponegoro \\ Korespondensi: ekozakiikhwan@gmail.com
}

\begin{abstract}
Background: Keluarga Sehat (KS) application is a system to provide data and information about family's health which expected to have benefit to the programmer in developing health promotion planning in health center. The benefit of this program would be maximized when man,organization and technology support each other. This study aims to evaluate the utilization of KS application and its effect to the performance of health promotion programmer in developing health programs.

Method: This is quantitative study with cross sectional approach to identify and examine causal relationships between user satisfaction, system utilization and health staff performance in health promotion programs. There were 60 health promotion staffs from health centers who were trained about KS application in 2016-2018 by Ministry of Health or Pati and Semarang City Health Offices were involved in this study. Independent variables consists of system quality, information quality, personal capability, leadership or management support, co-worker support and availability of facilities. Whilst, dependent variables consists of user satisfaction, system utilization and performance of health promotion staffs. The analysis of the system refers to HOT-Fit Model.

Results: Personal capability, system utilization, leadership or management supports have significantly positive influence on the performance of health promotion staffs. User satisfaction, co-worker support, availability of facilities, system quality and information quality both directly and indirectly through user satisfaction and system utilization did not have any significant influence on the performance of health promotion staffs. It is recommended to provide training in processing and analyzing data from the application as well as strengthening internet network and adding the server.

Keywords: application, performance, health promotion, HOT-Fit Model
\end{abstract}

\section{PENDAHULUAN}

Data dan informasi merupakan sumber daya yang penting bagi organisasi terutama sebagai dasar dalam perencanaan dan evaluasi program. ${ }^{(1)(2)}$ Data dan informasi bermanfaat sebagai input dalam proses pengambilan keputusan. Kebutuhan data dan informasi kesehatan dapat dipenuhi melalui penyelenggaraan pelayanan kesehatan di puskesmas yang terintegrasi pada semua program dengan memanfaatkan teknologi informasi untuk pemrosesan data. ${ }^{(1)}$

Data dan informasi kesehatan masyarakat sangat menentukan kualitas pelayanan di puskesmas. Dalam rangka mendukung upaya pelayanan dan penyediaan data kesehatan di puskesmas, Kementerian Kesehatan menggalakkan kembali program pelayanan kesehatan 
dengan sasaran utama adalah keluarga. Program yang disebut Program Indonesia Sehat dengan Pendekatan Keluarga (PISPK) ini dimaksudkan untuk mendekatkan masyarakat kepada akses pelayanan kesehatan. Program ini menekankan agar petugas puskesmas melakukan kunjungan keluarga untuk mendapatkan data profil kesehatan keluarga (prokesga) yang kemudian direkap melalui kuesioner keluarga (family folder). ${ }^{(3)}$ Data prokesga selanjutnya dientri melalui aplikasi keluarga sehat untuk dapat menyajikan data kesehatan keluarga sesuai 12 indikator keluarga sehat dan data Indikator Keluarga Sehat (IKS) berbasis kewilayahan.

Puskesmas sebagai pemberi pelayanan kesehatan tingkat pertama diharapkan mampu menyelenggarakan PISPK dengan mengintegrasikan pelayanan upaya kesehatan perorangan (UKP) dan upaya kesehatan masyarakat (UKM). Promosi kesehatan sebagai salah satu bentuk pelayanan UKM di puskesmas dilaksanakan melalui upaya peningkatan kemampuan masyarakat melalui pembelajaran dari, oleh, untuk dan bersama masyarakat sehingga masyarakat bisa mengenali masalah kesehatannya serta melakukan upaya kesehatan secara mandiri dalam mengatasi masalah kesehatan tersebut dengan memanfaatkan potensi yang ada di masyarakat. ${ }^{(4)(5)}$
Petugas promosi kesehatan puskesmas memiliki target kinerja yang sudah ditetapkan oleh Dinas Kesehatan Kabupaten/Kota dengan mengacu pada Renstra dari Dinas Kesehatan Propinsi Jawa Tengah. Di dalam Renstra Dinas Kesehatan Propinsi Jawa Tengah tahun 2013-2018 disebutkan bahwa indikator kinerja program promosi kesehatan meliputi proporsi desa/kelurahan siaga aktif mandiri, proporsi posyandu mandiri dan jumlah penyuluhan di luar gedung. ${ }^{(6)}$ Selain berpedoman pada renstra, perencanaan kegiatan di puskesmas juga harus disusun berdasarkan kebijakan pembangunan kesehatan yaitu PIS-PK. Artinya, perencanaan kegiatan dilakukan berdasarkan data dari aplikasi keluarga sehat. Dalam membuat perencanaan kegiatan, petugas promosi kesehatan harus melakukan analisis situasi berdasarkan data kesehatan keluarga, melakukan perumusan masalah serta memecahkan masalah melalui kegiatan promosi kesehatan. $^{(7)}$ Kualitas pelayanan dan perencanaan sangat ditentukan oleh kualitas informasi yang dihasilkan oleh sistem. ${ }^{(2)}$

Aplikasi keluarga sehat sebagai sistem informasi yang mampu menyediakan data kesehatan keluarga diharapkan dapat bermanfaat bagi pemegang program puskesmas khususnya petugas promosi kesehatan untuk membuat Rencana Usulan Kegiatan (RUK). Sistem informasi berguna untuk menghasilkan data dan informasi 
guna pengambilan keputusan. Perencanaan sebagai kegiatan pengambilan keputusan akan lebih tepat sasaran jika didasarkan pada data dan fakta yang ada. ${ }^{(2)}$ Informasi dibutuhkan untuk mengevaluasi pelaksanaan dan intervensi program, sebagai dasar dalam perencanaan program dan pengalokasian sumber daya dalam pembangunan kesehatan. ${ }^{(8)}$

Sejak diberikan pelatihan tentang pemanfaatan aplikasi Keluarga Sehat oleh Kementerian Kesehatan RI atau oleh Dinas Kesehatan Kabupaten/Kota (Kabupaten Pati/Kota Semarang) kepada para petugas promosi kesehatan, belum dilakukan evaluasi tentang pemanfaatan aplikasi tersebut dalam membuat perencanaan program kesehatan.

Penggunaan sistem informasi dalam suatu organisasi akan memberikan potensi manfaat yang maksimal pada peningkatan kinerja individu maupun organisasi apabila teknologi, manusia dan organisasi dapat saling mendukung satu dengan yang lainnya (Human, Organization and Technology-Fit). Model HOT-Fit ini merupakan model evaluasi implementasi sistem informasi yang relatif lebih lengkap dalam melihat faktor-faktor yang mempengaruhi penggunaan sistem informasi, karena di dalamnya ada faktor organisasi yaitu struktur dan lingkungan organisasi yang tidak diakomodir secara lengkap pada model yang lain. ${ }^{(9)}$
Faktor-faktor dalam model HOT-Fit meliputi faktor manusia, faktor organisasi dan faktor teknologi. Faktor manusia terdiri dari penggunaan sistem dan kepuasan pengguna. Penggunaan sistem meliputi: kapabilitas personal, penggunaan fungsi sistem, dan pengetahuan. Kepuasan pengguna meliputi: relevansi informasi, kemudahan, konsistensi, kehandalan sistem. Faktor organisasi terdiri dari struktur dan lingkungan organisasi. Struktur organisasi meliputi: dukungan pimpinan/ manajemen, dukungan rekan kerja, sistem kontrol, komunikasi. Lingkungan organisasi meliputi: pembiayaan, fasilitas, kompetisi, kebijakan pemerintah. Faktor teknologi terdiri dari kualitas sistem, kualitas informasi dan kualitas layanan. Kualitas sistem meliputi: kemudahan penggunaan, keamanan, fleksibilitas, ketersediaan. Kualitas informasi meliputi: kelengkapan informasi, akurasi, ketepatan waktu, ketersediaan, konsistensi. Kualitas layanan meliputi: kecepatan respon dan penanganan pelayanan. ${ }^{(9)}$

Berdasarkan penjelasan tersebut, peneliti tertarik untuk menganalisis pemanfaatan aplikasi keluarga sehat (yang ditentukan berdasarkan faktor teknologi, manusia dan organisasi) terhadap kinerja petugas promosi kesehatan dalam pembuatan RUK. Faktor teknologi meliputi kualitas sistem dan kualitas informasi. Faktor manusia meliputi kapabilitas 
personal, kepuasan pengguna dan pemanfaatan sistem. Faktor organisasi meliputi dukungan pimpinan/manajemen, dukungan rekan kerja dan ketersediaan fasilitas. Sedangkan kinerja petugas promosi kesehatan berhubungan dengan pembuatan RUK promosi kesehatan sesuai indikator kinerjanya, yaitu pengembangan desa/kelurahan siaga, pengembangan posyandu dan penyuluhan di luar gedung.

\section{METODE}

Penelitian ini telah lolos uji etik dari Komisi Etik Fakultas Kesehatan Masyarakat Universitas Diponegoro no. 12/EA/KEPK-FKM/2019.

Penelitian ini adalah penelitian asosiatif dengan bentuk hubungan kausal dan pendekatan waktu pengambilan data dilakukan secara cross sectional. Sampel penelitian sebanyak 60 petugas promosi kesehatan puskesmas, yang terdiri dari 44 petugas promosi kesehatan di Dinas Kesehatan Kabupaten Pati dan 16 petugas promosi kesehatan di Dinas Kesehatan Kota Semarang. Sampel dipilih berdasarkan kriteria inklusi yaitu petugas promosi kesehatan yang sudah mendapatkan pelatihan keluarga sehat dari Kemenkes RI atau Dinas Kesehatan Kabupaten/Kota tahun 2016-2018 serta masih bertugas sebagai pemegang program promosi kesehatan saat dilakukan penelitian.
Teknik pengumpulan data dengan menggunakan angket penelitian berskala likert 1-4 untuk menilai persepsi petugas promosi kesehatan tentang variabel penelitian. Variabel bebas pada penelitian ini adalah kualitas sistem, kualitas informasi, kapabilitas personal, dukungan pimpinan/manajemen, dukungan rekan kerja dan ketersediaan fasilitas. Variabel terikat terdiri dari kepuasan pengguna, pemanfaatan sistem dan kinerja petugas promosi kesehatan.

Analisis univariat variabel penelitian dideskripsikan dengan tabel distribusi frekuensi. Sedangkan analisis multivariat dengan outer model. Analisis outer model merupakan pengujian validitas dan reliabilitas indikator pada masing-masing variabel penelitian yang dilakukan dengan menggunakan software Smart PLS 3 versi student. Hasil uji validitas dilihat berdasarkan convergent validity dan discriminat validity. Model pada penelitian ini dilakukan pengujian tiga kali untuk mendapatkan indikator yang valid dan reliabel. Uji validitas berdasarkan convergent validity mensyaratkan bahwa untuk penelitian tahap pengembangan, nilai loading factor setiap indikator pada konstruknya $\geq 0,50 .^{(10)}$ Pada discriminat validity, model mempunyai discriminat validity yang cukup jika akar AVE (average variance extracted) untuk setiap konstruk lebih besar dari pada korelasi antara 
konstruk dengan konstruk lainnya. Model pada penelitian ini telah memenuhi convergent validity dan discriminat validity. Sedangkan uji reliabilitas pada penelitian ini berdasarkan reliabilitas konstruk, yaitu konstruk dinyatakan reliabel jika nilai composite reliability $>0,70 .{ }^{(10)}$ Model pada penelitian ini juga telah memenuhi validitas konstruk.

Hasil analisis outer model dengan indikator valid dan reliabel dapat dilihat pada gambar 1. Variabel kualitas sistem diukur dengan 6 indikator, yaitu kemudahan penggunaan, menu-menu berjalan sesuai fungsinya, keamanaan, kemudahan akses, tampilan menarik dan aplikasi menyediakan data untuk perencanaan, tetapi hanya indikator kemudahan penggunaan, tampilan menarik dan aplikasi menyediakan data untuk perencanaan yang memenuhi faktor loading $\geq 0,50$. Variabel kualitas informasi diukur dengan 6 indikator yaitu kelengkapan informasi, kemudahan pembacaan data, ketepatan waktu, keakuratan data, relevansi informasi dan informasi tersedia setiap saat, tetapi hanya indikator kelengkapan informasi, kemudahan pembacaan data dan relevansi informasi yang memenuhi faktor loading $\geq$ 0,50 .

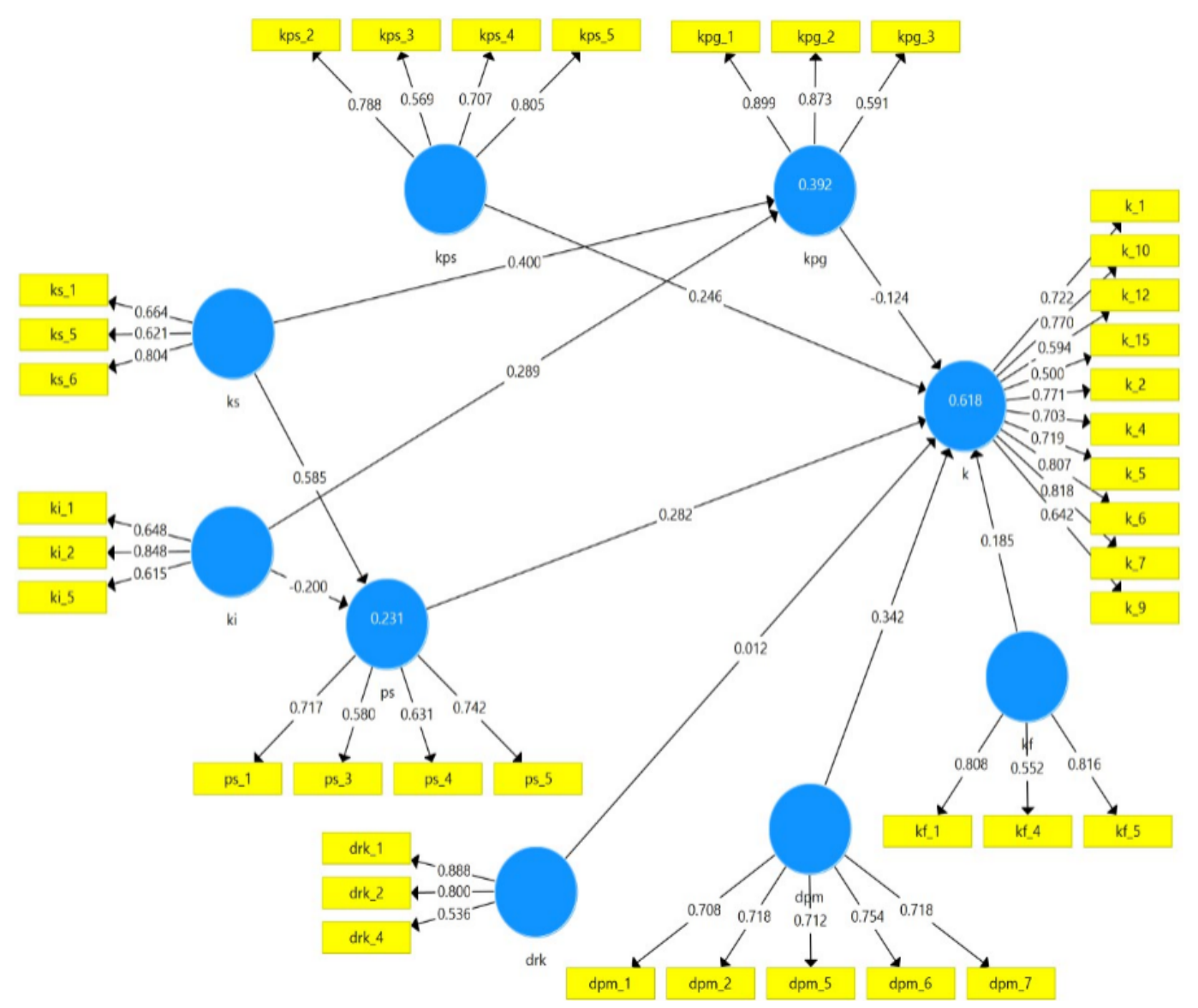

Gambar 1. Model dengan indikator valid dan reliabel 
Variabel kapabilitas personal diukur dengan 5 indikator, yaitu mampu menggunakan aplikasi, mampu menganalisis data, mengakses aplikasi untuk memperoleh data, mampu menginterpretasi data dan mengerti penggunaan buku manual aplikasi, tetapi hanya indikator mampu menganalisis data, mengakses aplikasi untuk memperoleh data, mampu menginterpretasi data dan mengerti penggunaan buku manual aplikasi yang memenuhi faktor loading $\geq 0,50$. Variabel kepuasan pengguna diukur dengan 5 indikator, yaitu puas dengan tampilan aplikasi, informasi sesuai kebutuhan perencanaan, tidak ada kendala dalam mengoperasikan aplikasi, informasi mencukupi kebutuhan perencanaan dan aplikasi mudah dioperasikan, tetapi hanya indikator puas dengan tampilan aplikasi, informasi sesuai kebutuhan perencanaan dan tidak ada kendala dalam mengoperasikan aplikasi yang memenuhi faktor loading $\geq 0,50$.

Variabel pemanfaatan sistem diukur dengan 5 indikator, yaitu frekuensi pemanfaatan, kualitas pemanfaatan, bisa mengekspor data ke program lain, mengakses aplikasi untuk mendapatkan data kesehatan keluarga dan mengunduh data IKS untuk perencanaan kegiatan, tetapi hanya indikator frekuensi pemanfaatan, bisa mengeksport data ke program lain, mengakses aplikasi untuk mendapatkan data kesehatan keluarga dan mengunduh data IKS untuk perencanaan kegiatan yang memenuhi faktor loading $\geq 0,50$.

Variabel dukungan pimpinan/ manajemen diukur dengan dengan 8 indikator, yaitu kepala puskesmas mendukung penggunaan aplikasi, kepala puskesmas mendukung pemanfaatan data, implementasi aplikasi dilaksanakan dengan baik, ada dukungan keuangan, manajemen mendukung pemanfaatan data untuk perencanaan, Dinas Kesehatan mendukung pemanfaatan data, ada pelatihan penggunaan aplikasi dan ada pelatihan analisis data dari aplikasi, tetapi hanya indikator kepala puskesmas mendukung penggunaan aplikasi, kepala puskesmas mendukung pemanfaatan data, manajemen mendukung pemanfaatan data untuk perencanaan, Dinas Kesehatan mendukung pemanfaatan data dan ada pelatihan penggunaan aplikasi yang memenuhi faktor loading $\geq 0,50$.

Variabel dukungan rekan kerja diukur dengan 4 indikator, yaitu rekan kerja mendukung penggunaan data untuk perencanaan, ada komunikasi untuk memanfaatkan data, rekan kerja menggunakan data untuk perencanaan dan rekan kerja membantu mengakses aplikasi, tetapi hanya indikator rekan kerja mendukung penggunaan data untuk perencanaan, ada komunikasi untuk memanfaatkan data dan rekan kerja 
membantu mengakses aplikasi yang memenuhi faktor loading $\geq 0,50$. Variabel ketersediaan fasilitas diukur dengan 5 indikator, yaitu dukungan internet, dukungan komputer, dukungan modem/ paket data, dukungan smartphone dan dukungan dana, tetapi hanya indikator dukungan internet, dukungan smartphone dan dukungan dana yang memenuhi faktor loading $\geq 0,50$.

Variabel kinerja petugas promosi kesehatan diukur dengan 16 indikator, yaitu menganalisis data, mengidentifikasi masalah prioritas, menggunakan parameter tertentu untuk menentukan masalah prioritas, mengidentifikasi akar penyebab masalah, menyusun kegiatan promosi kesehatan, merencanakan diseminasi informasi, merencanakan pemberdayaan masyarakat, merencanakan pemberdayaan kader, merencanakan kegiatan advokasi, merencanakan penyuluhan, merencanakan pembuatan media cetak, rencana yang dibuat sejalan dengan masalah prioritas puskesmas, rencana memberikan andil dalam mengatasi masalah, rencana yang dibuat dihargai manajemen puskesmas, rencana sejalan dengan renstra Dinas Kesehatan dan memberikan saran kepada rekan kerja untuk menggunakan data dari aplikasi, tetapi hanya indikator menganalisis data, mengidentifikasi masalah prioritas, mengidentifikasi akar penyebab masalah, menyusun kegiatan promosi kesehatan, merencanakan diseminasi informasi, merencanakan pemberdayaan masyarakat, merencanakan kegiatan advokasi, merencanakan penyuluhan, rencana yang dibuat sejalan dengan masalah prioritas puskesmas dan rencana sejalan dengan renstra Dinas Kesehatan yang memenuhi faktor loading $\geq$ 0,50 .

\section{HASIL DAN PEMBAHASAN}

\section{Karakteristik Responden}

Karakteristik responden yang diteliti meliputi umur, jenis kelamin, usia, pendidikan terakhir dan masa kerja seperti terlihat pada Tabel 1. Hasil penelitian menunjukkan dari 60 responden penelitian, sebagian besar responden berjenis kelamin perempuan $(81,67 \%)$ dengan usia paling banyak antara 25-29 tahun (38,33\%) dan pendidikan terakhir sebagian besar adalah D4 - S1 (66,67\%). Masa kerja responden paling banyak antara 1-5 tahun (53,33\%).

Untuk menggambarkan jawaban responden terhadap variabel penelitian, jawaban responden dikategorikan menjadi "tidak setuju" dan "setuju". Untuk jawaban "sangat tidak setuju" dikategorikan menjadi "tidak setuju" dan jawaban "sangat setuju" dikategorikan menjadi "setuju". Persepsi responden tersebut dapat dilihat pada tabel 2. 
Tabel 1. Karakteristik responden

\begin{tabular}{lrr}
\hline Karakteristik Responden & \multicolumn{1}{c}{$\mathrm{f}$} & $\%$ \\
\hline Jenis Kelamin & & \\
Laki-laki & 11 & 18,33 \\
Perempuan & 49 & 81,67 \\
Usia & & \\
$20-24$ & 2 & 3,33 \\
$25-29$ & 23 & 38,33 \\
$30-34$ & 9 & 15,00 \\
$35-39$ & 13 & 21,67 \\
$40-44$ & 4 & 6,67 \\
$45-49$ & 7 & 11,67 \\
$\geq 50$ & 2 & 3,33 \\
Pendidikan Terakhir & & \\
D1 - D3 & 19 & 31,66 \\
D4-S1 & 40 & 66,67 \\
S2 & 1 & 1,67 \\
Masa Kerja & & \\
$1-5$ & 32 & 53,33 \\
$6-10$ & 14 & 23,33 \\
$11-15$ & 2 & 3,33 \\
$16-20$ & 2 & 3,33 \\
$21-25$ & 5 & 8,33 \\
$26-30$ & 5 & 8,33 \\
\hline
\end{tabular}

Tabel 2. Distribusi frekuensi persepsi responden terhadap variabel penelitian

\begin{tabular}{llrr}
\hline \multicolumn{1}{c}{ Variabel } & \multicolumn{1}{c}{ Indikator } & $\begin{array}{r}\text { Tidak setuju } \\
(\%)\end{array}$ & $\begin{array}{c}\text { Setuju } \\
(\%)\end{array}$ \\
\cline { 2 - 3 } & Kemudahan penggunaan & 8,33 & 91,67 \\
sistem & Menu-menu berjalan sesuai fungsinya & 26,67 & 73,33 \\
& Aplikasi mengalami error & 53,33 & 46,67 \\
& Kemudahan akses & 46,67 & 53,33 \\
& Tampilan menarik & 25,00 & 75,00 \\
& Aplikasi menyediakan data untuk perencanaan & 20,00 & 80,00 \\
Kualitas & Kelengkapan informasi & 61,67 & 38,33 \\
informasi & Kemudahan pembacaan data & 26,67 & 73,33 \\
& Ketepatan waktu & 23,33 & 76,67 \\
& Keakuratan data & 31,67 & 68,33 \\
& Relevansi informasi & 6,67 & 93,33 \\
Kapabilitas & 36,67 & 63,33 \\
personal & Informasi tersedia setiap saat & 15,00 & 85,00 \\
& Mampu menggunakan aplikasi & 13,33 & 86,67 \\
& Mampu menganalisis data & 13,33 & 86,67 \\
& Mengakses aplikasi untuk memperoleh data & 15,00 & 85,00 \\
& Mampu menginterpretasi data & 15,00 & 85,00 \\
\hline
\end{tabular}


Tabel 2. Lanjutan

\begin{tabular}{|c|c|c|c|}
\hline Variabel & Indikator & $\begin{array}{c}\text { Tidak setuju } \\
(\%)\end{array}$ & $\begin{array}{c}\text { Setuju } \\
(\%)\end{array}$ \\
\hline \multirow{5}{*}{$\begin{array}{l}\text { Kepuasan } \\
\text { pengguna }\end{array}$} & Puas dengan tampilan aplikasi & 21,67 & 78,33 \\
\hline & Informasi sesuai kebutuhan perencanaan & 31,67 & 68,33 \\
\hline & Tidak ada kendala dalam mengoperasikan aplikasi & 41,67 & 58,33 \\
\hline & Informasi mencukupi kebutuhan perencanaan & 45,00 & 55,00 \\
\hline & Aplikasi mudah dioperasikan & 50,00 & 50,00 \\
\hline \multirow{5}{*}{$\begin{array}{l}\text { Pemanfaatan } \\
\text { sistem }\end{array}$} & Sering menggunakan & 30,00 & 70,00 \\
\hline & Mampu mengeksplor menu-menu & 18,33 & 81,67 \\
\hline & Bisa mengeksport data ke program lain & 13,33 & 86,67 \\
\hline & $\begin{array}{l}\text { Mengakses aplikasi untuk mendapatkan data } \\
\text { kesehatan keluarga }\end{array}$ & 5,00 & 95,00 \\
\hline & Mengunduh data IKS untuk perencanaan kegiatan & 15,00 & 85,00 \\
\hline \multirow{8}{*}{$\begin{array}{l}\text { Dukungan } \\
\text { pimpinan/ } \\
\text { manajemen }\end{array}$} & $\begin{array}{l}\text { Kepala puskesmas mendukung penggunaan } \\
\text { aplikasi }\end{array}$ & 0 & 60,00 \\
\hline & Kepala puskesmas mendukung pemanfaatan data & 8,33 & 91,67 \\
\hline & Implementasi aplikasi dilaksanakan dengan baik & 45,00 & 55,00 \\
\hline & Ada dukungan keuangan & 33,33 & 66,67 \\
\hline & Manajemen mendukung pemanfaatan data & 11,67 & 88,33 \\
\hline & Dinas Kesehatan mendukung pemanfaatan data & 11,67 & 88,33 \\
\hline & Ada pelatihan penggunaan aplikasi & 6,67 & 93,33 \\
\hline & Ada pelatihan analisis data dari aplikasi & 8,33 & 91,67 \\
\hline \multirow[t]{4}{*}{$\begin{array}{l}\text { Dukungan } \\
\text { rekan kerja }\end{array}$} & $\begin{array}{l}\text { Rekan kerja mendukung penggunaan data untuk } \\
\text { perencanaan }\end{array}$ & 13,33 & 86,67 \\
\hline & Ada komunikasi untuk memanfaatkan data & 16,67 & 83,33 \\
\hline & Rekan kerja menggunakan data untuk perencanaan & 26,67 & 73,33 \\
\hline & Rekan kerja membantu mengakses aplikasi & 40,00 & 60,00 \\
\hline \multirow{5}{*}{$\begin{array}{l}\text { Ketersediaan } \\
\text { fasilitas }\end{array}$} & Dukungan internet & 0 & 100,00 \\
\hline & Dukungan computer & 23,33 & 76,67 \\
\hline & Dukungan modem/ paket data & 30,00 & 70,00 \\
\hline & Dukungan smartphone & 48,33 & 51,67 \\
\hline & Dukungan dana & 8,33 & 91,67 \\
\hline \multirow{13}{*}{$\begin{array}{l}\text { Kinerja } \\
\text { petugas } \\
\text { promkes }\end{array}$} & Menganalisis data & 0 & 100,00 \\
\hline & Mengidentifikasi masalah prioritas & 3,33 & 96,67 \\
\hline & $\begin{array}{l}\text { Menggunakan parameter tertentu untuk } \\
\text { menentukan masalah prioritas }\end{array}$ & 15,00 & 85,00 \\
\hline & Mengidentifikasi akar penyebab masalah & 11,67 & 88,33 \\
\hline & Menyusun kegiatan promosi kesehatan & 3,33 & 96,67 \\
\hline & Merencanakan diseminasi informasi & 1,67 & 98,33 \\
\hline & Merencanakan pemberdayaan masyarakat & 5,00 & 95,00 \\
\hline & Merencanakan pemberdayaan kader & 15,00 & 85,00 \\
\hline & Merencanakan kegiatan advokasi & 5,00 & 95,00 \\
\hline & Merencanakan penyuluhan & 6,67 & 93,33 \\
\hline & Merencanakan pembuatan media cetak & 25,00 & 75,00 \\
\hline & $\begin{array}{l}\text { Rencana yang dibuat sejalan dengan masalah } \\
\text { prioritas puskesmas }\end{array}$ & 3,33 & 96,67 \\
\hline & $\begin{array}{l}\text { Rencana memberikan andil dalam mengatasi } \\
\text { masalah }\end{array}$ & 21,67 & 78,33 \\
\hline
\end{tabular}


Tabel 2. Lanjutan

\begin{tabular}{llcc}
\hline \multirow{2}{*}{ Variabel } & \multicolumn{1}{c}{ Indikator } & $\begin{array}{c}\text { Tidak setuju } \\
(\%)\end{array}$ & $\begin{array}{c}\text { Setuju } \\
(\%)\end{array}$ \\
\cline { 2 - 4 } & $\begin{array}{l}\text { Rencana yang dibuat dihargai manajemen } \\
\text { puskesmas }\end{array}$ & 8,33 & 91,67 \\
& $\begin{array}{c} \\
\text { Rencana sejalan dengan renstra Dinas Kesehatan }\end{array}$ & 3,33 & 96,67 \\
& $\begin{array}{l}\text { Memberikan saran kepada rekan kerja untuk } \\
\text { menggunakan data dari aplikasi }\end{array}$ & 13,33 & 86,67 \\
\hline
\end{tabular}

\section{Analisis Inner Model}

Analisis inner model dimaksudkan untuk mengetahui besar pengaruh varibel bebas terhadap variabel terikat berdasarkan nilai R-square.

Tabel 3. Besar pengaruh variabel bebas terhadap variabel terikat

\begin{tabular}{lc}
\hline \multicolumn{1}{c}{ Variabel } & $R$-square \\
\hline Kinerja petugas & 0,618 \\
promosi kesehatan & \\
Kepuasan pengguna & 0,392 \\
Pemanfaatan sistem & 0,231 \\
\hline
\end{tabular}

Tabel 3 menjelaskan mengenai besar pengaruh variabel bebas terhadap variabel terikat. Variabel kinerja petugas promosi kesehatan memiliki nilai $R$-square sebesar 0,618, artinya variabel kinerja petugas promosi kesehatan dapat dijelaskan oleh variabel kapabilitas personal, kepuasan pengguna, pemanfaatan sistem, dukungan pimpinan/manajemen, dukungan rekan kerja dan ketersediaan fasilitas sebesar $61,8 \%$, sedangkan $38,2 \%$ dijelaskan variabel lain di luar model.

Variabel kepuasan pengguna memiliki nilai $R$-square sebesar 0,392, itu artinya variabel kepuasan pengguna dapat dijelaskan oleh variabel kualitas sistem dan kualitas informasi sebesar 39,2\%, sedangkan $60,8 \%$ dijelaskan oleh variabel lain diluar model. Variabel pemanfaatan sistem memiliki nilai $R$-square sebesar 0,231 , artinya variabel pemanfaatan sistem dapat dijelaskan oleh variabel kualitas sistem dan kualitas informasi sebesar $23,1 \%$, sedangkan $76,9 \%$ dijelaskan variabel lain di luar model.

\section{Pengujian Hipotesis}

Hasil estimasi $\mathrm{t}$ statistik dan nilai koefisien korelasi antar variabel dapat dilihat pada tabel 4 .

\section{Pengaruh Kualitas terhadap Kinerja Petugas Promosi Kesehatan}

Kualitas sistem berpengaruh positif signifikan terhadap pemanfaatan sistem $(\mathrm{t}$ statistik $=3,707, \quad$ koefisien $\quad$ korelasi $=$ 0,585), tetapi kualitas sistem tidak berpengaruh terhadap kinerja petugas promosi kesehatan baik secara langsung maupun tidak langsung melalui pemanfaatan sistem. Pengguna akan memanfaatkan sistem jika menganggap sistem tersebut bermanfaat untuk membantu pekerjaannya. ${ }^{(11)}$ 
Tabel 4. Hubungan antar variabel

\begin{tabular}{lcc}
\hline \multicolumn{1}{c}{ Variabel } & $\begin{array}{c}\text { Koefisien } \\
\text { korelasi }\end{array}$ & $\begin{array}{c}\mathrm{t} \\
\text { statistik }\end{array}$ \\
\hline $\begin{array}{l}\text { Pengaruh dukungan pimpinan/manajemen terhadap kinerja petugas } \\
\text { promkes }\end{array}$ & 0,342 & 3,221 \\
Pengaruh dukungan rekan kerja terhadap kinerja petugas promkes & 0,012 & 0,056 \\
Pengaruh ketersediaan fasilitas terhadap kinerja petugas promkes & 0,185 & 1,496 \\
Pengaruh kualitas Informasi terhadap kepuasan pengguna & 0,289 & 2,165 \\
Pengaruh kualitas informasi terhadap pemanfaatan sistem & $-0,200$ & 1,184 \\
Pengaruh kepuasan pengguna terhadap kinerja petugas promkes & $-0,124$ & 1,243 \\
Pengaruh kapabilitas personal terhadap kinerja petugas promkes & 0,246 & 1,980 \\
Pengaruh kualitas sistem terhadap kepuasan pengguna & 0,400 & 2,257 \\
$\begin{array}{l}\text { Pengaruh kualitas sistem terhadap pemanfaatan sistem } \\
\text { Pengaruh pemanfaatan sistem terhadap kinerja petugas promkes }\end{array}$ & 0,585 & 3,707 \\
$\begin{array}{l}\text { Pengaruh kualitas sistem terhadap kinerja petugas promkes } \\
\text { Pengaruh kualitas informasi terhadap kinerja petugas promkes }\end{array}$ & 0,282 & 1,981 \\
$\begin{array}{l}\text { Pengaruh kualitas sistem terhadap kinerja petugas promkes melalui } \\
\text { kepuasan pengguna }\end{array}$ & $-0,095$ & 0,913 \\
Pengaruh kualitas sistem terhadap kinerja petugas promkes melalui & 0,046 & 0,974 \\
pemanfaatan sistem & 0,143 & 1,585 \\
$\begin{array}{l}\text { Pengaruh kualitas informasi terhadap kinerja petugas promkes } \\
\text { melalui kepuasan pengguna }\end{array}$ & $-0,049$ & 0,952 \\
$\begin{array}{l}\text { Pengaruh kualitas informasi terhadap kinerja petugas promkes } \\
\text { melalui pemanfaatan sistem }\end{array}$ & $-0,046$ & 0,928 \\
\hline
\end{tabular}

Semakin cocok sistim dengan pekerjaan, maka pengguna akan meningkatkan penerimaannya. Pemanfaatan sistem akan semakin rendah jika sistem sulit digunakan dan diakses. Faktor kesesuaian tugas dan kompleksitas sistem berpengaruh terhadap pemanfaatan sistem. ${ }^{(12)}$ Sebagian besar petugas promosi kesehatan telah mengidentifikasi dan menganalisis data dari aplikasi walaupun kualitas sistem dari aplikasi kadang masih mengalami error dan sulit diakses.

Kualitas informasi berpengaruh positif signifikan terhadap kepuasan pengguna $\quad(\mathrm{t}$ statistik $=2,165, \quad$ koefisien korelasi $=0,289$ ). Sedangkan kualitas informasi tidak berpengaruh terhadap kinerja petugas promosi kesehatan baik secara langsung maupun tidak langsung melalui kepuasan pengguna. Sebagian besar responden sudah menganalisis data dan mengidentifikasi masalah kesehatan dari aplikasi, tetapi $61,67 \%$ responden menyatakan aplikasi belum menyediakan informasi kesehatan keluarga yang lengkap. Ini menunjukkan bahwa responden sudah menggunakan data dari aplikasi untuk membuat RUK walaupun informasi yang dihasilkan aplikasi belum lengkap.

Hasil penelitian tentang evaluasi implementasi sistem e-learning menemukan bahwa kualitas informasi berpengaruh terhadap kepuasan pengguna. ${ }^{(13)}$ Informasi sebagai sumber 
daya yang dibutuhkan oleh tenaga kesehatan untuk memperoleh gambaran kondisi masyarakat guna membuat perencanaan. Kualitas informasi yang dihasilkan sistem sangat menentukan kualitas pelayanan dan kualitas perencanaan. $^{(2)}$

Kualitas informasi tidak berpengaruh terhadap pemanfaatan sistem $(\mathrm{t}$ statistik $=$ $1,184$, koefisien korelasi $=-0,200)$. Kualitas informasi juga tidak berpengaruh terhadap kinerja petugas promosi kesehatan baik secara langsung maupun tidak langsung melalui pemanfaatan sistem. Petugas promosi kesehatan menggunakan data dari aplikasi untuk membuat RUK walaupun aplikasi belum menyediakan informasi yang lengkap. Hal ini karena adanya kebijakan PIS-PK dan akreditasi puskesmas, dimana pemegang program puskesmas diharapkan dapat membuat perencanaan dengan dasar data yang ada.

\section{Pengaruh Kapabilitas Personal dengan} Kinerja Petugas Promosi Kesehatan

Kapabilitas personal terbukti berpengaruh positif signifikan terhadap kinerja petugas promosi kesehatan (t statistik $=1,980$, koefisien korelasi $=$ 0,246). Penelitian tentang kemampuan teknik pemakai dan faktor-faktor yang mempengaruhi kinerja individu menunjukkan bahwa terdapat pengaruh yang positif antara kemampuan teknik personal terhadap kinerja individual. ${ }^{(14)(15)}$ Variabel keterampilan, pengetahuan dan pelatihan juga berhubungan dengan kinerja petugas promosi kesehatan. ${ }^{(16)}$

Kapabilitas personal menentukan kemampuan pengguna dalam menggunakan sistem. Kemampuan pengguna yang semakin baik akan mengoptimalkan pemanfaatan sistem. Dari hasil penelitian menunjukkan bahwa kemampuan pengguna dalam memanfaatkan aplikasi, mengakses data, melakukan analisis, serta interpretasi data mampu meningkatkan kinerja pengguna dalam membuat RUK.

\section{Pengaruh Kepuasan Pengguna dengan Kinerja Petugas Promosi Kesehatan}

Kepuasan pengguna tidak berpengaruh terhadap kinerja petugas promosi kesehatan $(\mathrm{t}$ statistik $=1,243$, koefisien $\quad$ korelasi $=-0,124)$. Pendapat responden berkaitan dengan kepuasan dalam menggunakan aplikasi menunjukkan bahwa $45 \%$ responden menyatakan informasi yang dihasilkan dari aplikasi belum mencukupi kebutuhan perencanaan di puskesmas dan 50\% responden tidak puas karena aplikasi masih mengalami kendala ketika dioperasikan. Sedangkan pada kinerja, $100 \%$ responden menyatakan telah menganalisis data dari aplikasi dan 96,67\% responden membuat perencanaan kegiatan berdasarkan data dari aplikasi. Ini menunjukkan bahwa pengguna sudah 
memanfaatakan data dari aplikasi untuk perencanaan walaupun belum memiliki kepuasan yang baik terhadap aplikasi. Kepuasan pengguna mempengaruhi minat seseorang untuk menggunakan sistem yang selanjutnya akan mempengaruhi persepsi kemanfaatan yang dirasakan oleh pengguna. $^{(17)(18)}$

\section{Pengaruh Pemanfaatan Sistem dengan}

\section{Kinerja Petugas Promosi Kesehatan}

Pemanfaatan sistem berpengaruh positif signifikan terhadap kinerja petugas promosi kesehatan ( $\mathrm{t}$ statistik $=1,981$, koefisien $\quad$ korelasi $=0,282$ ). Petugas promosi kesehatan sebagian besar memiliki persepsi positif terhadap pemanfaatan sistem, yaitu sudah mengunduh data IKS dari aplikasi (85\%), sering membuka aplikasi $(70 \%)$ serta menggunakan aplikasi untuk mendapatkan data kesehatan keluarga (95\%). Dari sisi kinerja, 100\% responden sudah melakukan analisis data dan 96,67\% responden melakukan identifikasi masalah kesehatan dari aplikasi. Aplikasi digunakan oleh pemegang program puskesmas untuk mendapatkan data kesehatan keluarga guna membuat RUK. Pemanfaatan teknologi informasi yang tepat dengan dukungan keterampilan dari pemakai akan dapat meningkatkan kinerja individu maupun kinerja organisasi. ${ }^{(19)}$ Penelitian tentang analisis pengaruh sistem informasi manajemen terhadap efektifitas kerja pegawai menunjukkan bahwa sistem informasi manajemen berpengaruh terhadap efektifitas kerja pegawai. ${ }^{(20)}$

\section{Pengaruh Dukungan Pimpinan/ Manajemen dengan Kinerja Petugas Promosi Kesehatan \\ Dukungan pimpinan/ manajemen} berpengaruh positif signifikan terhadap kinerja petugas promosi kesehatan $(\mathrm{t}$ statistik $=3,221, \quad$ koefisien $\quad$ korelasi $=$ 0,342). Dalam pemanfaatan teknologi informasi, kebijakan dan dukungan pimpinan/manajemen akan berpengaruh terhadap keberhasilan penerapan teknologi informasi. Dukungan pimpinan/manajemen akan mempengaruhi minat pengguna dalam memanfaatkan teknologi informasi. ${ }^{(21)}$ Hasil penelitian tentang faktor-faktor yang menentukan efektifitas sistem informasi pada organisasi sektor publik menemukan bahwa manajemen puncak, manajemen sistem informasi dan penggunaan sistem informasi berpengaruh positif pada efektifitas sistem informasi. $^{(22)}$

\section{Pengaruh Dukungan Rekan Kerja} dengan Kinerja Petugas Promosi Kesehatan

Dukungan rekan kerja tidak berpengaruh signifikan terhadap kinerja petugas promosi kesehatan $(\mathrm{t}$ statistik = 0,056, koefisien korelasi $=0,012$ ). Sebagian besar responden berpendapat bahwa rekan 
kerja tidak membantu jika responden kesulitan mengakses aplikasi (40\%). Pada umumnya, dukungan rekan kerja hanya sebatas komunikasi untuk menggunakan data dari aplikasi tetapi tidak memberikan bantuan secara teknis dalam memanfaatkan data tersebut untuk pembuatan RUK. Petugas promosi kesehatan lebih banyak mengandalkan kemampuannya sendiri untuk membuat rencana kegiatan.

\section{Pengaruh Ketersediaan Fasilitas dengan}

\section{Kinerja Petugas Promosi Kesehatan}

Ketersediaan fasilitas tidak berpengaruh signifikan terhadap kinerja petugas promosi kesehatan $(\mathrm{t}$ statistik $=$ 1,496, koefisien korelasi $=0,185)$. Ini berarti bahwa dukungan fasilitas yang ada tidak mempengaruhi kinerja petugas promosi kesehatan dalam membuat RUK. Semua pemegang program diharuskan membuat RUK sesuai target kinerja masing-masing. Rencana kegiatan yang telah dibuat akan di bahas oleh tim manajemen puskesmas untuk dilakukan prioritas kegiatan yang bisa dikerjakan dengan menyesuaikan anggaran puskesmas dan penanganan masalah prioritas.

\section{SIMPULAN}

Penggunaan aplikasi keluarga sehat yang ditentukan berdasarkan variabel kapabilitas personal, pemanfaatan sistem dan dukungan pimpinan/ manajemen memberikan pengaruh positif terhadap kinerja petugas promosi kesehatan dalam pembuatan RUK. Penggunaan aplikasi keluarga sehat yang ditentukan berdasarkan variabel kepuasan pengguna, dukungan rekan kerja, ketersediaan fasilitas, serta kualitas sistem dan kualitas informasi baik secara langsung maupun tidak langsung melalui kepuasan pengguna dan pemanfaatan sistem tidak berpengaruh terhadap kinerja petugas promosi kesehatan dalam membuat RUK.

Teknologi informasi akan dimanfaatkan oleh pengguna jika teknologi tersebut mudah digunakan dan diakses, dapat membantu pekerjaan serta mampu menyediakan data untuk perencanaan kegiatan. Pemanfaatan teknologi informasi yang baik akan mampu meningkatkan kinerja pengguna. Perlu pemberian pelatihan cara pengolahan dan analisis data dari aplikasi, penguatan jaringan internet di puskesmas, penambahan server untuk aplikasi serta kebijakan pemanfaatan data untuk perencanaan kegiatan.

\section{Ucapan Terima Kasih}

Ucapan terima kasih penulis tujukan kepada Pusat Peningkatan Mutu SDMK Badan PPSDMK Kementerian Kesehatan RI yang telah memberikan dukungan sumber dana dalam pelaksanaan penelitian ini serta Magister Kesehatan Masyarakat Fakultas Kesehatan Masyarakat Universitas 
Diponegoro tempat peneliti menempuh pendidikan lanjut.

\section{KEPUSTAKAAN}

1. Kementerian Kesehatan RI. Petunjuk Teknis Aplikasi Keluarga Sehat. Jakarta : Kemenkes RI; 2017.

2. Asminiarti E. Analisis Penyusunan Perencanaan Kegiatan Dinas Kesehatan Kabupaten Jepara Berdasarkan Pemanfaatan laporan Sistem Informasi Kesehatan [skripsi]. Semarang: Program Magister Ilmu Kesehatan Masyarakat; 2015.

3. Kementerian Kesehatan RI. Pedoman Umum Program Indonesia Sehat Dengan Pendekatan Keluarga. Jakarta: Kemenkes RI; 2016.

4. Kementerian Kesehatan RI. Promosi

Kesehatan di Daerah Bermasalah Kesehatan Panduan bagi Petugas Kesehatan di Puskesmas. Jakarta: Kemenkes RI; 2011.

5. Keputusan Menteri Kesehatan RI Nomor 1114

/MENKES/SK/VII/2005. Tentang Pedoman Pelaksanaan Promosi Kesehatan di Daerah.

6. Dinas Kesehatan Provinsi Jawa Tengah. Rencana Strategis Dinas Kesehatan Provinsi Jawa Tengah Tahun 2013-2018. Semarang: Dinas Kesehatan Provinsi Jawa Tengah;
2013.

7. Peraturan Menteri Kesehatan RI No. 44 Tahun 2016 tentang Pedoman Manajemen Puskesmas.

8. WHO. Health Metrics Network: Framework and Standars for Country Health Information System 2nd Edition. Geneva: WHO Press; 2008.

9. Yusof MM, Kuljis J, Papazafeiropoulou A, Stergioulas LK. An evaluation framework for Health Information Systems: human, organization and technology-fit factors (HOT-fit). International Journal of Medical Informatics. 2008;77(6):386-98.

10. Ghozali I. Structural Equation Modeling Metode Alternatif Dengan Partial Least Squares (PLS). Semarang: Badan Penerbit Universitas Diponegoro; 2014.

11. Hamid AA, Razak FZA, Bakar AA, Abdullah WSW. The Effects of Perceived Usefulness and Perceived Ease of Use on Continuance Intention to Use E-Government. Procedia Economics and Finance. 2016;35(October 2015):644-9.

12. Martins C, Oliveira T, Popovič A. Understanding The Internet Banking Adoption: A Unified Theory of Acceptance and Use of Technology and Perceived Risk Application. International Journal of Information 
Management. 2014;34(1):1-13.

13. Poluan F, Lumenta A, Sinsuw A. Evaluasi Implementasi Sistem ELearning Menggunakan Model Evaluasi HOT Fit Studi Kasus Universitas Sam Ratulangi. E-journal Teknologi Informatika. 2014;4(2):16.

14. Alannita NP, Suaryana IGNA. Pengaruh Kecanggihan Teknologi Informasi, Partisipasi Manajemen Dan Kemampuan Teknik Pemakai Sistem Informasi Akuntansi Pada Kinerja Individu. 2014;1:33-45.

15. Wirawan BS, Suardikha IMS.

Faktor-Faktor yang Mempengaruhi Kinerja Individual pada Bank Perkreditan Rakyat di Kabupaten Badung. E-Jurnal Akuntansi Universitas Udayana. 2016;17(3):2352-83.

16. Yuniarti, Shaluhiyah Z, Widjanarko B. Kinerja Petugas Penyuluh Kesehatan Masyarakat dalam Praktek Promosi Kesehatan di Dinas Kesehatan Kabupaten Pati. Jurnal Promosi Kesehatan Indonesia. 2012;7(2):165-73.

17. Tam C, Oliveira T. Does Culture Influence M-Banking Use and Individual Performance? Information \& Management. 2018;56(July):356-63.

18. Gursel,G.,Zayim,N.,Gulkesen,K.H.,
Arifoglu, A., Saka O. A New Approach in The Evaluation of Hospital Information System. Turkish Journal of Electrical Enginering Computer Science. 2014;22:214-22.

19. Nasir A, Oktari R. Pengaruh Pemanfaatan Teknologi Informasi dan Pengendalian Intern terhadap Kinerja Instansi Pemerintah (Studi Pada Satuan Kerja Perangkat Daerah Kabupaten Kampar). Jurnal Ekonomi Universitas Riau. 2011;19(02):1-14.

20. Dewi HSR. Analisis Pengaruh Sistem Informasi Manajemen terhadap Efektivitas Kerja Pegawai pada Bidang Sumber Daya Kesehatan Dinas Kesehatan Provinsi Jawa Barat [tesis]. Bandung: Magister Ilmu Administrasi Universitas Pasundan; 2013.

21. Kabra G, Ramesh A, Akhtar P, Dash MK. Understanding Behavioural Intention to Use Information Technology: Insights from Humanitarian Practitioners. Telematics and Informatics Journal. 2017;34(7):1250-61.

22. Handayani R. Analisis Faktor-Faktor yang Menentukan Efektivitas Sistem Informasi pada Organisasi Sektor Publik. Jurnal Akuntansi dan Keuangan. 2010;12:26-40. 